\title{
HEAT STRESS IN POULTRY. I. DANGER, RELATED PHYSIOLOGICAL CHANGES AND SYMPTOMS* (review)
}

\section{V.I. FISININ, A.Sh. KAVTARASHVILI}

All-Russian Research and Technological Poultry Institute, Federal Agency of Scientific Organizations, 10, ul. Ptitsegradskaya, Sergiev Posad-11, Moscow Province, 141300 Russia, e-mail fisinin@vnitip.ru, alexk@vnitip.ru Received January 19, 2015

\section{Abstract}

Data on heat stress in poultry are surveyed in a two-part review. In the first part presented herein the authors summarized current knowledge on the influence of heat stress on alterations of metabolic and physiological processes in poultry as well as the adverse consequences for livability, growth, development and productivity, being 19.3-28.8 \% less, and product quality (M.M. Mashaly et al., 2004; Sh. Imangulov et al., 2005). The level of these alterations depends on strength and durability of the exposure to stressing conditions, on age of birds, type and level of productivity, health status, nutrition program, complex of genetic factors, rearing conditions, etc. (J.O. Ayo et al., 2006; A. Kavtarashvili, T. Kolokolnikova, 2010). Heat stress triggers a wide range of behavioral, physiological and immunological alterations in poultry (J.O. Ayo et al., 2006; P.F. Surai, T.I. Fotina, 2013) as a result of intricate interactions between decreased feed consumption up to $-34.7 \%$ (M.M. Mashaly et al., 2004; Z. Abidin, A. Khatoon, 2013), disturbances of endocrine (B.Y.L. Hai et al., 2000; Y.A. Attia et al., 2009) and acid-base (S.A. Borges et al., 2004) balances, impaired antioxidant status, abnormal function of definite organs and mechanisms (P. Surai, T. Fotina, 2010). Heat stress enhances the synthesis of corticosterone, noradrenaline and adrenaline which suppress releasing and distribution of steroids and gonadotropins, thus activating deregulation mechanisms fundamental for follicular growth and development as well as the ovulation (A. Yakubu et al., 2007; Y. Song et al., 2009; A.O. Oguntunji, O.M. Alabi, 2010). Additionally, the synthesis and releasing of vitellogenin necessary for the deposition of yolk is suppressed (M. Ciftci et al., 2005). The activity and efficiency of lymphoid organs such as bursa, spleen, thymus are also impaired, the numbers of monocytes, lymphocytes and heterophils are increased (O. Altan et al., 2000; S.M. Naseem et al., 2005) resulting in impaired immune response in poultry (V. Savic et al., 1993). The antioxidant status is decreased resulting in higher levels of oxidative stress when the balance between the production of free radicals and levels of antioxidants able to neutralize them is disturbed (L.T. Kadim et al., 2008). The weight of small intestine and absorbing surface of intestinal villi are also decreased by $22-23 \%$ and $19 \%$, respectively (W.G. Bottie, P.C. Harrison, 1987; M.A. Mitchell, A.J. Carlisle, 1992). The functions of thyroid, particularly synthesis of $T_{3}$ hormone, and pancreas, namely secretion of trypsin, chymotrypsin and amylase, are suppressed (B.Y.L. Hai et al., 2000; Y.A. Attia et al., 2009). The acidity and bactericide activity of gastric juice and choleretic function of liver are decreased, the balance between beneficial and detrimental segments of intestinal microbial population is altered (K. Suzuki et al., 1983; J.A. Tur, R.V. Rial, 1985) while blood supply of gastrointestinal tract, especially its upper part, is inadequate (D. Wolfenson et al., 1981). Blood vessels in skin, wattles and combs are dilated (R.U. Khan et al., 2012). Attempts to maintain the thermal homeostasis result in shallow and active breathing which is 5 to 6 times more frequent in thermal stressed (panting) birds (M.K. Sabah Elkheffi et al., 2008; A.O. Oguntunji, O.M. Alabi, 2010). That leads to increased clearance of carbon dioxide necessary for synthesis of calcium carbonate for eggshell formation, followed by subsequent increase in blood $\mathrm{pH}$ and respiratory alkalosis, the overall disturbance of acid-base balance (R.G. Teeter et al., 1985; A.Sh. Kavtarashvili et al., 2003; S.A. Borges et al., 2004).

Keywords: temperature, heat stress, poultry, physiological changes, poultry productivity.

Heat stress triggers a wide range of behavioral, physiological and immunological changes in poultry, which leads to decrease in feed consumption,

\footnotetext{
* «Heat stress in poultry. II. Methods and techniques for prevention and mitigation» is given in the Sel'skokhozyaistvennaya biologiya/Agricultural Biology, 2015, V. 50, № 4.
} 
growth and development rate, egg-laying capacity, incubative and commercial qualities of eggs, viability of poultry, etc. [1,2]. Sharp temperature rise may lead to mass mortality of stock. The process is aggravated in the cage technology of poultry management and increases with the number of tiers in the equipment. The mortality of poultry is especially high at upper tiers of batteries. This inevitably results in big financial losses. Thus, according to available data, annual losses in the US poultry industry from heat stress are equal to 128-165 mln dollars [3].

Heat stress hazard. Heat stress occurs as a result of negative balance between the amount of heat energy supplied from the environment to the animal and released by the animal. It causes a wide spectrum of physiological changes depending on stress intensity and duration [4]. A number of researchers believe that the factors influencing the heat stress intensity include maximum temperature value, high temperature exposure duration, temperature variation within 24 hours, relative air humidity, poultry genotype and age $[5,6]$.

With regard to physiology, poultry somewhat differs from other warmblooded animals and can live without serious deviations in the organism in a very narrow range of ambient temperatures. Birds have no sweat glands; their vasomotor reaction is weak, thermoreceptors are localized in the skin, tongue and brain, and heat-regulating center is located in the hypothalamus [3].

Four overheating phases are distinguished based on changes in heat exchange in poultry [7]: I - stable adaptation of organism to high temperatures; II - total heat load is not compensated by water evaporation from the surface of the body and respiratory passages (hyperemia of arteriovenous anastomoses, increase in mean and rectal temperature); III - external heat load dominates over heat dissipation in the course of water evaporation from the surface of the body and respiratory passages (start of poultry mass mortality events); IV - heat apoplexy with specific signs of collapse.

It is proposed to assess potential heat stress hazard by calculating a Hazard Index (HI) which takes into account both temperature $\left(\mathrm{T},{ }^{\circ} \mathrm{C}\right)$ and relative humidity $(\mathrm{RH}, \%)$ [8]: $\mathrm{HI}=(1.8 \mathrm{~T}+32)+\mathrm{RH}$. There is an assumption [9] that poultry feels comfortable when HI is below 150 . Productivity begins to decline when HI is within 150-160. In the HI range within 160-165, feed consumption decreases, whereas water consumption increases. When HI rises up to 165-170, mortality becomes substantially higher along with mass lesion of the respiratory and blood circulatory system, and crossing of $\mathrm{HI}=170$ involves the mass mortality of poultry.

K.E. Anderson and T.A. Carter [10] indicate the following temperature ranges affecting the health and productivity of poultry. At $13-24{ }^{\circ} \mathrm{C}$ (thermoneutral zone), poultry does not need to change basic metabolism or behavior in order to maintain body temperature. Ideal temperature range is 18$24{ }^{\circ} \mathrm{C}$. Insignificant decrease in feed consumption may be observed within 24$29^{\circ} \mathrm{C}$, however, it is unlikely that the productivity will be affected if nutrient intake is adequate. Nevertheless, some loss of egg weight and shell quality is noted, especially upon reaching the upper limit of the mentioned range. At 29$32{ }^{\circ} \mathrm{C}$, feed consumption continues to decrease. Significant reduction is observed in respect to such parameters as daily average live weight gain in young stock, egg-laying capacity of chickens, weight and shell quality of eggs (a cooldown procedure shall be initiated before these temperature values are achieved). Then $\left(32-35^{\circ} \mathrm{C}\right)$, feed consumption continues to decrease, and there is a heat stress risk, especially for highly productive poultry (active measures are needed to cool the poultry house). At $35-38^{\circ} \mathrm{C}$, heat stress is inevitable, and feed consumption and productivity significantly decrease along with sharp in- 
crease in water consumption (emergency measures shall be taken). At $38{ }^{\circ} \mathrm{C}$ and above, poultry life is in danger, and urgent measures for poultry house cooldown are required.

Changes in bird organism in case of heat stress. As noted above, this taxonomic group of animals has limited resources for responding to environmental factor fluctuations and initiating protection mechanisms. Adaptation to new conditions requires the redistribution of organism reserves due to decrease in growth and reproductive function [11].

Birds respond to high air temperatures by changing the level of hormones, glucose, leukocytes and electrolytes circulating in blood. Thus, the increased production of corticosterone, noradrenaline and adrenaline is observed during heat stress, which causes follicle degeneration and leads to decrease in egg-laying capacity $[12,13]$. Then, the activity and performance efficiency of lymphoid organs (bursa, spleen and thymus) decrease and the number of monocytes, lymphocytes and heterophils [14, 15] increases, which results in lower immune response [16].

Under heat stress conditions, bird blood plasma volume increases, while the concentration of other components (for example, thyroxin, erythrocytes, hemoglobin, amino acids, calcium) decreases [2, 17]. Decrease is also observed in respect to such parameters as oxygen consumption, nitrogen exchange, content of metabolic water in organism and content of vitamins $\mathrm{A}, \mathrm{B}_{2}$ and $\mathrm{C}$ in liver. In addition, a change is observed in the ratio between the activity of carbohydrate and lipid exchange [18, 19]. The amount of fat increases with simultaneous decrease in live weight; increase in concentration is noted for triglycerides in blood, glycogen in liver and myocard and adenosine monophosphate in plasma, liver, muscles and fat tissues; lipid peroxidation occurs in cell membranes [12, 20, 21].

Heat stress is characterized by decrease in antioxidant status in poultry, which leads to higher oxidative stress associated with imbalance between the production of free radicals and the number of the antioxidants neutralizing them. Free radicals are able to damage all types of biological molecules, including lipids, proteins and nucleic acids [22]. It is known that about 200 billion free radicals are produced in each cell every day. This figure increases by several times under stress conditions. This results in cell membrane abnormalities leading to harmful effects for cell metabolism [23-25].

It is common knowledge that the digestive system of birds readjusts itself in accordance with the amount and quality of consumed feed. Higher nutrient rate in the diet leads to increase in excretion of corresponding enzymes into the gastrointestinal tract and vice versa. In poultry, high temperature causes reflectory increase in cutaneous blood flow and decrease in blood circulation in internal organs; the associated decrease in feed consumption is equal to $1.5 \%$ per degree above $20{ }^{\circ} \mathrm{C}[2,26,27]$.

Many researchers have established that heat stress $\left(35^{\circ} \mathrm{C}\right)$ against the background of lesser feed consumption by poultry leads to $22-23 \%$ decrease in small intestine weight and $19 \%$ reduction in the absorbing surface of villi [28, 29]. This results in lesser digestibility and absorption of nutrients, as well as accessibility of amino acids, fat and starch, which is also associated with the depression of thyroid function, in particular, hormone $T_{3}$ production [30-32], as well as with reduction in secretion of pancreatic enzymes, such as trypsin, chymotrypsin and amylase [6, 33]. There are also other changes in the gastrointestinal tract: reduction in acidity and bactericide function of gastric juice, decrease in bile excretion function of liver, changes in the balance of beneficial and harmful intestinal microflora [34, 35], as well as decrease in gastrointestinal blood flow, especially in upper segments [36]. These deviations disappear after 
poultry return to thermoneutral conditions (at least in case of individuals with preliminary acclimatization) [37].

With rise of ambient temperature, in order to restore heat balance with the environment, the bird stretches the wings and slows down its motor activity; in this case, depth of breathing decreases and rate of breathing increases by a factor of about 5-6 [2, 13, 38]. The blood vessels of skin, wattles and combs dilate, and internal heat is supplied to the skin surface, through which the bird organism cools down due to convection (heat radiation) [25].

The correct combination of air temperature and velocity can provide an ideal balance between heat energy production in poultry and heat losses through skin. If there is no temperature differential between air and skin, then air velocity will not have any influence on bird thermal regulation [39].

If the amount of heat generated in the organism exceeds its release rate for a long time, bird body temperature will begin to increase along with drastic reduction in the efficiency of heat dissipation through skin. In such a situation, a main way of cooling to maintain thermal homeostasis is evaporation via breathing $[8,13]$. When ambient temperature is above $30^{\circ} \mathrm{C}$, bird breathing accelerates from 22-25 to 200-250 cycles per minute [7, 40]. If the evaporative cooling mechanism becomes insufficient, poultry may die [41, 42]. It has been established that the energy required for poultry to lose $1 \mathrm{~g}$ of water due to evaporative cooling is equal to about $540 \mathrm{cal}[43,44]$. In case of heat stress, water loss may be $5-10 \mathrm{~g}$ per day, i.e. it may achieve almost all required heat loss with evaporation [39]. Water consumption may increase approximately by $6.5 \%$ per each degree above $21{ }^{\circ} \mathrm{C}$ [45]. Water consumption stimulation promotes the evaporative cooling mechanism [46]. The feed to water consumption ratio at high temperatures increases from 2:1 to 5:1 [44, 47].

As noted above, attempts of birds to maintain homeostasis under heat stress conditions lead to breathing acceleration (for heat dissipation due to evaporation) with increase in the rate of carbon dioxide removal from the organism (carbon dioxide is required for formation of calcium carbonate which is a component of shell). As a consequence, blood $\mathrm{pH}$ increases, which, in turn, leads to acid-base imbalance, in particular, respiratory alkalosis. At high ambient temperature, this alkalosis is characterized by low concentrations of calcium and sodium bicarbonate, $\mathrm{CO}_{2}$ and $\mathrm{HCO}_{3}$, in blood [48-50].

The alkalosis is a shift of acid-base balance in the organism to the alkaline reaction due to changes in the content of standard (energy-independent) acids and alkalis. This condition is accompanied by the change of the ratio between plasma electrolytes and blood gases affecting the formation of the high-quality shell of eggs [51]. Chickens suffer mild alkalosis at $35^{\circ} \mathrm{C}(\mathrm{pH}=7.55)$, moderate alkalosis at $38{ }^{\circ} \mathrm{C}$ and severe alkalosis at $41{ }^{\circ} \mathrm{C}(\mathrm{pH}=7.65)$ [52]. Any strategy aimed at maintaining $\mathrm{CO}_{2}$ and/or $\mathrm{HCO}_{3}$ amount within a physiologically normal range can mitigate some of negative consequences of heat stress [53].

During heat stress, animal cells try to retain water by accumulating potassium ions. As a rule, increase in the concentration of other ions adversely affect metabolic processes [6].

Heat stress signs. Heat stress in young poultry exhibits primarily in decrease in feed consumption and growth slowdown [54]. Thus, feed consumption decreases by $1.4 \%, 1.6 \%$ and $2.3 \%$ when temperature rises from 20 to $25{ }^{\circ} \mathrm{C}, 25$ to $30^{\circ} \mathrm{C}$ and 30 to $35{ }^{\circ} \mathrm{C}$, respectively; above $35^{\circ} \mathrm{C}$, it decreases by $4.8 \%$ per $1{ }^{\circ} \mathrm{C}$ [55]. The puberty of hens is delayed by $8-10$ days [56], and roosters, to the contrary, mature earlier, but the volume of semen and content of spermatozoa decrease [19]. Poultry survivability decreases, and high temperatures are especially critical for broiler chickens at the age from 20 days until slaughter 
[57]. At the same time, carcass quality deterioration is noted, in particular, disruption of skin during defeathering, poor bleeding, coarse meat with dark pigmentation and changes in biochemical composition (lower protein content, higher fat fraction in carcass). PSE (Pale, Soft, Exudate) syndrome (or «soft muscle tissue») develops in pectoral muscle. The pectoral muscle meat becomes pale and loose, and watery exudate is noted during dissection (it is a result of protein denaturation at high temperature). In case of deep processing, such meat loses its consumer properties and nutritional value, which leads to reduction in price of the obtained product [57]. A shift of acid-base balance occurs, causing respiratory alkalosis [52].

Feed consumption by adult poultry also decreases (by 3-5\% when ambient temperature rises from 25 to $28{ }^{\circ} \mathrm{C}$ and $20-25 \%$ when it rises up to $33{ }^{\circ} \mathrm{C}$ ) along with digestive enzyme activity [58-60]. Water consumption increases 1.4 times in case of temperature rise from 21 to $27^{\circ} \mathrm{C}, 2.5$ times in a range up to $33{ }^{\circ} \mathrm{C}[61,62]$, and $2-3$ times from 35 to $40{ }^{\circ} \mathrm{C}$. Excessive water consumption leads to craw sagging, which provokes pathogenic microflora reproduction in the craw, intestine and lungs [57]. The rate of breathing increases as temperature rises [49, 63]. A shift of acid-base balance occurs along with development of respiratory alkalosis $[3,52]$. Egg weight decreases [58, 64]. In particular, it have been established that above $24{ }^{\circ} \mathrm{C}$ it decreases by $0.5-1.0 \%$ per $1{ }^{\circ} \mathrm{C}$ of rising temperature [65, 66]. Based on other data [55], within $23-27{ }^{\circ} \mathrm{C}$, egg weight decreases by $0.4 \%$ and above $27{ }^{\circ} \mathrm{C}$ by $0.8 \%$ per $1{ }^{\circ} \mathrm{C}$ of rising temperature.

The egg-laying capacity of hens decreases by $2.7 \%$ per $1{ }^{\circ} \mathrm{C}$ when ambient temperature rises from 21 to $38^{\circ} \mathrm{C}$ [67]. The temperature rise is especially critical for old hens (due to depression of ovary and egg tube function). It is reported that, at temperature above $30 \mathrm{C}$, the egg-laying capacity of 35-44-week, 45-54-week and 55-64-week hens decreases by $5 \%, 12 \%$ and $24 \%$, respectively $[27,59]$. A main cause of reproductive function decline in chickens in heat stress conditions supposedly consists in the reduction of blood supply in ovary vessels along with increase in cutaneous blood flow [68, 69]. This is evidenced by the significant reduction in the ovary weight and number of large follicles, which was observed for White Leghorn chickens on days 6 and 15 in heat stress conditions $\left(42^{\circ} \mathrm{C}\right)$, as compared to the individuals kept in the thermoneutral zone [69]. Stress hormones (corticosterone, noradrenaline and adrenaline) have an antagonistic effect on reproductive function via brain, hypophysis and gonads, including the reduction of normal ovary function, which leads to suppression of secretion of steroids (progesterone and estradiol) and gonadotrophins (luteinizing and folliclestimulating hormones). This results in abnormal regulation of the physiological mechanisms which are of fundamental importance for steroidogenesis, follicle development and growth, and ovulation [13, 70-72].

In addition, impairment is observed with regard to the synthesis and release of vitellogenin needed for egg yolk formation [58]. The egg laying interval within one cycle extends, being $25.6 \mathrm{~h}$ at $21^{\circ} \mathrm{C}$ and $27.7 \mathrm{~h}$ at $31^{\circ} \mathrm{C}$ [27]. The egg shell thickness decreases along with the microstructural failure of both organic and mineral parts of the shell $[60,73]$. This is caused by reduction in feed (and calcium) consumption by $25-30 \%$ due to increased water consumption, as well as by faster passage of feed through the gastrointestinal tract [49]. Blood outflows to skin and calcium feeding of uterus becomes abnormal $[69,72]$; calcium carbonate content in blood decreases in connection with hurried bird breathing and accelerated carbon dioxide removal from the organism [60]; the ability of duodenum cells to absorb calcium decreases [74, 75]; the activity of carbonic anhydrase (an enzyme promoting shell formation) declines [72, 76]. The Ca- 
carrying capacity of blood decreases (as a result of alkalosis) [3, 77].

Thyroid function depression occurs, which prevents the generation of the active form of vitamin $\mathrm{D}_{3}$ in kidneys [60].

Bird body temperature increases $[8,31,71]$ within the range of air temperatures from 35 to $40{ }^{\circ} \mathrm{C}$ by $0.5-1.0^{\circ} \mathrm{C}$, and from 41 to $44{ }^{\circ} \mathrm{C}$ by $1.5-2.0^{\circ} \mathrm{C}$, comatose condition of birds is observed, and mass mortality occurs after 12 hours under high temperature conditions [59].

Egg hatchability decreases along with poultry immunity and survivability $[15,78]$. Sperm quality deteriorates (reduction in semen volume and live spermatozoon motility and number) [79, 80]. The mineral depletion of muscular and bone tissues (especially in thigh bones) takes place, which results in so-called «cage fatigue» syndrome in highly productive poultry [60].

Thus, high ambient temperature is one of the key non-genetic factors influencing the physiological condition of poultry. Heat stress inevitably leads to the changes in the bird organism, which affect all the systems and organs and influence such parameters as feed and water consumption, nutrient digestibility, growth, development, productivity, product quality and immunity of poultry. As a consequence, disease incidence increases and production efficiency decreases. The depth of changes depends on heat stress intensity and duration, poultry age, usage type and productivity level, veterinary safety of the farm, feeding quality, a set of process and genetic factors, etc. In order to develop efficient measures for preventing heat stress and mitigating its adverse effects (especially when stocking rate is significant in the conditions of large farms), in-depth studies of fundamental processes in the bird organism are required, in particular, with regard to the physiological and molecular mechanisms of thermal regulation and adaptation. In addition, continuous monitoring of ambient conditions is needed for the operational evaluation of potential heat stress hazard.

\section{REFER E N C E S}

1. Progressivnye resursosberegayushchie tekhnologii proizvodstva yaits [Resource-saving technologies in egg production]. V.I. Fisinin, A.Sh. Kavtarashvili (eds.). Sergiev Posad, 2009.

2. Imangulov Sh., Kavtarashvili A., M n u y a n V. Ptitsevodstvo, 2005, 9: 29-30.

3. Surai P.F., Foti n a T.I. Tvarinnitstvo s'ogodni, 2013, 6: 54-60.

4. A y o J.O., D z e n d a T., $\mathrm{N}$ w e n y i O.A. Effect of ascorbic acid on diurnal variation in rectal temperature of Yankasa sheep during the early rainy season. Proc. $31^{\text {st }}$ Annual conference of Nigerian Society for Animal Production (NSAP). Bayero University, Kano, 2006: 143-147.

5. Li n H., Ji a o H.C., B u y s J., D e cuy pere E. Strategies for preventing heat stress in poultry. World's Poult. Sci. J., 2006, 62: 71-86 (doi: 10.1079/WPS200585).

6. Atti a Y.A., H a s s a n R.A., Q o t a M.A. Recovery from adverse effects of heat stress on slow-growing chicks in the tropics. 1: Effect of ascorbic acid and different levels of betaine. Tropical Animal Health and Production, 2009, 41: 807-818 (doi: 10.1007/S11250-008-9256-9).

7. M a r kin Yu.V., S p i ridonov D.N., Z e vak va V.K., P o lu ni na S.V. Kombikorma, 2011, 4: 59-60.

8. Podobed L.I., Fisinin V.I., Egorov I.A., Okole lova T.M. Kormovye $i$ tekhnologicheskie narusheniya $v$ ptitsevodstve $i$ ikh profilaktika [Fodder and technological violations and their prevention]. Ukraina, Odessa, 2013.

9. Grechikhin S.N. Prakticheskoe rukovodstvo po vyrashchivaniyu broilerov [A practical guide on broiler growing]. Ukraina, Kiev, 2007.

10. Anders o n K.E., Carte r T.A. Hot weather management of poultry. Poultry Science and Technology Guide (North Carolina State University), 2004, 30: 6.

11. Khan R.U., Naz S., Nikousefat Z., Tufarelli V., Javadani M., Rana N., L a u d a d i o V. Effect of vitamin E in heat-stressed poultry. World's Poult. Sci. J., 2011, 67: 469-477 (doi: 10.1017/S0043933911000511).

12. S a hi n K., K u c u k O. Heat stress and dietary vitamin supplementation of poultry diets. Nutrition Abstracts and Reviews, Series B: Livestock Feeds and Feeding, 2003, 73: 41-50.

13. Oguntunji A.O., Alabi O.M. Influence of high environmental temperature on egg production and shell quality: a review. World's Poult. Sci. J., 2010, 66: 739-749 (doi: 10.1017/S004393391000070X). 
14. Altan O., Altan A., Cabuk M., B a y raktar H. Effect of heat stress on some blood parameter in broilers. Turk Veternerlik Ve Hayvancilik Dergisi, 2000, 24: 145-148.

15. N a s e e m S.M., A n w a r Y.B., G hafoo r A., As 1 a m A., A k h t e r S. Effect of ascorbic acid and acetylsalicylic acid supplementation on performance of broiler chicks exposed to heat stress. Int. J. Poult. Sci., 2005, 4: 900-904.

16. Savic V., Mike c M., Pavicic P., Tis ijar M. Effect of repeated heat stress on the humoral immune response and productivity of broiler chicks. Veterinarska Stanica, 1993, 24: 195-202.

17. M ashaly M.M., Hendricks G.L., Kala ma M.A., Gehad A.E., Abbas A.O., $\mathrm{Pat}$ ers on P.H. Effect of heat stress on production parameters and immune responses of commercial laying hens. Poult. Sci., 2004, 83: 889-894 (doi: 10.1093/PS/83.6.889).

18. Te e te r R.G., S m it h M.O. High chronic ambient temperature stress effects on broiler acidbase balance and their response it supplemental ammonium chloride, potassium chloride and potassium carbonate. Poult. Sci., 1986, 65: 1777-1781.

19. Fis in in V.I., I mangulov Sh.A., Kavta rashvili A.Sh. Povyshenie effektivnosti yaichnogo ptitsevodstva [Improving the efficiency of egg poultry farming]. Sergiev Posad, 2001.

20. $\mathrm{Al}-\mathrm{G}$ h a $\mathrm{mdi}$ Z.H. Effects of commutative heat stress on immunoresponses in broiler chickens reared in closed system. Int. J. Poult. Sci., 2008, 7: 964-968 (doi: 10.3923/ijps.2008.964.968).

21. Kadim L.T., Ai-Q amshui B.H.A., Mahgoub O., Ai-Marzooqi W., Johnson E.H. Effect of seasonal temperatures and ascorbic acid supplementation on performance of broiler chickens maintained in closed and open-sided houses. Int. J. Poult. Sci., 2008, 7: 655-660 (doi: 10.3923/ijps.2008.655.660).

22. Surai P., Foti na T. Efektivne ptakhivnitstvo, 2010, 8(68): 20-25.

23. F is in i n V.I., S u r a i P. Ptitsa i ptitseprodukty, 2011, 5: 23-26.

24. Surai P., F is i ni n V.I. Sel'skokhozyaistvennaya Biologiya [Agricultural Biology], 2012, 4: $3-13$.

25. Khan R.U., Naz S., Nikousefat Z., Selvaggi M., Laudadio V., Tufarelli V. Effect of ascorbic acid in heat-stressed poultry. World's Poult. Sci. J., 2012, 68: 477-489 (doi: 10.1017/S004393391200058X).

26. How lide r M.A.R., Rose S.P. Temperature and the growth of broilers. World's Poult. Sci. J., 1987, 43: 228-237.

27. Kavtaras hvili A.Sh. RatsVetInform, 2012, 7: 9-12.

28. B otti e W.G., H a r ris o n P.C. Celiac cyclic blood flow pattern response to feeding and heat exposure. Poult. Sci., 1987, 66: 2039-2042.

29. Mitchell M.A., Carlisle A.J. The effects of chronic exposure to elevated environmental temperature on intestinal morphology and nutrient absorption in the domestic fowl (Gallus domesticus). Comparative Biochemistry and Physiology. Part A: Physiology, 1992, 101: 137-142.

30. S a h i n K., K u c u k O. Effects of vitamin $\mathrm{C}$ and vitamin $\mathrm{E}$ on performance, digestion of nutrients, and carcass characteristics of Japanese quails reared under chronic heat stress $\left(34^{\circ} \mathrm{C}\right) . J$. Anim. Physiol. Anim. Nutr., 2001, 85: 335-342.

31. Garriga C., Hunter R.R., A mat C., P la nas J.M., Mitchell M.A., More to M. Heat stress increases apical glucose transport in the chicken jejunum. American Journal of Physiology-Regulatory, Integrative and Comparative Physiology, 2006, 290(1): 195-201.

32. M c N a b b F.M.A. The hypothalamic-pituitary-thyroid (hpt) axis in birds and its role in bird development and reproduction. Crit. Rev. Toxicol., 2007, 37: 163-193.

33. Ha i B.Y.L., Rong D., Z hang Z.Y. The effect of thermal environment on the digestion of broilers. J. Anim. Physiol. Anim. Nutr., 2000, 83: 57-64.

34. Suzuki K., Harasawa R., Yoshttake Y., Mitsuoka T. Effects of crowding and heat stress on intestinal flora, body weight gain, and feed efficiency of growing rats and chicks. Nippon Juigaku Zasshi, 1983, 45: 331-338.

35. Tu r J.A., Ri a l R.V. The effect of temperature and relative humidity on the gastrointestinal motility of young broilers. Comp. Biochem. Physiol. (A), 1985, 80: 481-486.

36. Wolfenson D., Fre i Y.F., S n a p e r N., B e r n a m A. Heat stress effects on capillary blood flow and its redistribution in the laying hen. Pflugers Archives, 1981, 390: 86-93.

37. Gonza lez-Es que rra R., Le es on S. Physiological and metabolic responses of broilers to heat stress - implications for protein and amino acid nutrition. World's Poult. Sci. J., 2006, 62: 282-295 (doi: 10.1079/WPS200597).

38. Sabah Elkheffi M.K., Mohammed Ahmed M.M., Abdel Gadir S.M. Effect of feed restriction and ascorbic acid supplementation on performance of broiler chicks reared under heat stress. Research Journal of Animal and Veterinary Sciences, 2008, 3: 1-8.

39. Me ij e r h of R. Overheated chick calculations. World Poultry, 2011, 1: 16-17.

40. Nillipour A.H., M log H. Feeding techniques during heat stress. Poultry Digest, 1999, 58(3): 34 .

41. Puron D., S a ntamaria R., S e gura J.C. Effect of sodium bicarbonate, on broilers performance in a acetylsalicylic, and ascorbic acid in tropical environment. J. Appl. Poultry 
Res., 1994, 3: 141-145.

42. Sahi n K., S a hi n N., Ku cuk O., Hayi rli A., Pras ad A.S. Role of dietary zinc in heat-stressed poultry: a review. Poultry Science, 2009, 88: 2176-2183 (doi: 10.3382/PS.200900117).

43. Mikhailovskaya O., Medvedenko A., Stepane nko V. Temperaturnyi stress $u$ kur nesushek $v$ zharkii period goda [Heat stress in laying hens in the hot season]. Hy-Line International, 2010 (http://www.hyline.com).

44. Holik V. Management of laying hens to minimize heat stress. Lohmann Information, 2009, 44(1): 16.

45. Ross 208. Parent stock management manual. Ross Breeders Limited, Huntsville, Alabama, USA, 1994, V. 4.

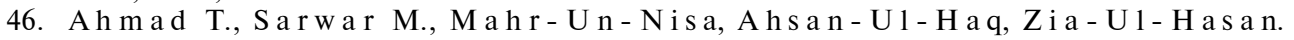
Influence of varying sources of dietary electrolytes on the performance of broilers reared in a high temperature environment. Animal Feed Science and Technology, 2005, 120: 277-298 (doi: 10.1016/j.anifeedsci.2005.02.028).

47. B a $1 \mathrm{n}$ a v e D., B r a k J. Nutrition and management of heat-stressed pullets and laying hens. World's Poult. Sci. J., 2005, 61: 399-406 (doi: 10.1079/WPS200565).

48. T e e ter R.G., S mith M.O., Owe ns F.N., A rp S.C., S a ngiah S., B re a zdle J.E. Chronic heat stress and respiratory alkalosis: occurrence and treatment in broiler chickens. Poultry Science, 1985, 64: 1060-1064.

49. Kavta rashvili A.SH., I mangulov SH.A., Okole lova T.M. Ptitsa i ptitseprodukty, 2003, 4: 22-25.

50. Borges S.A., Fischer Da Silva A.V., Majorka A., Hooge D.M., $\mathrm{Cummings}$ K.R. Physiological responses of broiler chicken to heat stress and electrolyte balance (sodium plus potassium minus chloride, milliequivalent per kilogram). Poultry Science, 2004, 83: 1551-1558 (doi: 10.1093/PS/83.9.1551).

51. Dorland N.W. Dorland's Illustrated Medical Dictionary. $24^{\text {th }}$ ed. W.B. Saunders, Philadelphia, USA, 1965.

52. A h mad T., S a r w a $\mathrm{r}$ M. Dietary electrolyte balance: implications in heat stressed broilers. World's Poult. Sci. J., 2006, 62: 638-653 (doi: 10.1079/WPS2006118).

53. Te e te r R.G., B e la y T. Broiler management during heat stress. Animal Feed Science and Technology, 1996, 58: 127-142.

54. A b id in $Z$., K hat o o n $A$. Heat stress in poultry and the beneficial effects of ascorbic acid (vitamin C) supplementation during periods of heat stress. World's Poult. Sci. J., 2013, 69: 135151 (doi: 10.1017/S0043933913000123).

55. Lohmann Tierzucht GmbH. Management Guide. Hot Climate. Cuxhaven, Germany, 2011.

56. Vo R.V., B o o ne M.A., H u g he s B.L., K n e $\mathrm{chtges}$ J.P. Effects of ambient temperature on sexual maturity in chickens. Poultry Science, 1980, 59: 2532-2537.

57. S piridonov D.N., Zevakova V.K., A k op y a n A.V. Ptitsa i ptitseprodukty, 2012, 1: $40-41$.

58. Ciftci M., Ertas O.N., Guler T. Effects of vitamin E and vitamin C dietary supplementation on egg production and egg quality of laying hens exposed to a chronic heat stress. Revue de Medecine Veterinaire, 2005, 156: 107-111.

59. Kavta ras hvili A., Kol o k ol' ni k ova T. Zhivotnovodstvo Rossii, 2010, 5-6: 17-20.

60. Kavtarashvili A.Sh., Kolokol'nikova T.N. Materialy Mezhdunarodnogo veterinarnogo kongressa «Aktual'nye veterinarnye problemy v promyshlennom ptitsevodstve» [Proc. Int. Congr. "Actual problems of veterenary medicine in the poultry industry»]. Moscow, 2013: 129-132.

61. K a vt a r a s hvili A.Sh. Ptitsevodstvo, 2012, 7: 13-17.

62. K a vt a ras hvili A.Sh. Zhivotnovodstvo Rossii, 2012, 9: 13-14.

63. Kavtarashvili A.Sh., O k ole lova T.M. BIO, 2002, 4(19): 34-37.

64. Kavt a r a s hvili A.SH. Feniks-Kus (Kazakhstan), 2010, 5: 25-27.

65. K a vt a r a s hvili A.SH. Efektivne ptakhivnitstvo, 2008, 4(40): 38-40.

66. Kavt a r a h vili A.SH. RatsVetInform, 2009, 2(90): 7-9.

67. David A. How house environment affects bird performance. Poultry International, 1982, 21(2): $68-78$

68. M a rsh R.L., D a w s o n W.R. Avian adjustment to cold. In: Advances in comparative and environmental physiology: animal adaptation to cold. L.C.H. Wang (ed.). NY, Springer-Verlag, 1989: 206-253.

69. Rozenboim I., Tako E., Gal-Garber O., Proudman J.A., Uni Z. The effect of heat stress on ovarian function of laying hens. Poultry Science, 2007, 86: 1760-1765 (doi: 10.1093/PS/86.8.1760)

70. Y a k u bu A., S a la k o A.E., I g e O. Effect of genotype and housing systems on the laying performance of chickens in different season in the semi-humid tropics. Int. J. Poult. Sci., 2007, 6(6): 434-439 (doi: 10.3923/ijps.2007.434.439).

71. Oguntunji A.O., Aderemi F.A., Lawal T.E., Alabi O.M. The influence of seasonal variation on performance of a commercial laying strein in a derived savanna environment in Nigeria. Nigerian Poultry Science Journal, 2008, 5(2): 67-74. 
72. S o ng Y., Wang C., Wang C., Lv L., Che n Y., Z h u o Z. Exogenous leptin promotes the recovery of regressed ovary in fasted ducks. Anim. Reprod. Sci., 2009, 110: 306-318.

73. K a v t a r a s hvili A.Sh., O k o le lov a T.M. Suchasne ptakhivnitstvo, 2007, 12(61): 4-9.

74. C a m p be 11 J.R., Ke $\mathrm{n}$ e a ly M.D., C a m p bell K.L. Physiology of egg laying. In: Animal sciences. The biology, care and production of domestic animals (4th ed.). NY, McGraw-Hill Higher Education, USA, 2003: 283-294.

75. Franco-Ji m e ne z D.J., S c he idele r S.E., Kittok R.J., Brown-Brandl T.M., R o b e s o n L.R., T a i r a H., B e c k V.V. Differential effects of heat stress in the strains of laying hens. J. Appl. Poult. Res., 2007, 16: 628-634.

76. Balnave D., Yose 11 ewiz I., D ix on R. Physiological changes associated with the production of defective egg-shells by hens receiving sodium chloride in the drinking water. $\mathrm{Br}$. J. Nutr., 1989, 61: 35-53.

77. S m it h A.J. Tropical agriculturist: Poultry. Revised edition. Macmillan Education Limited, London and Oxford, UK, 2001: 123-158.

78. Te mi m S., C hag n e a u A., Peres s o n M., Tess e ra u d S. Chronic heat exposure alters protein turnover of three different skeletal muscles in finishing broiler chickens fed 20 or $25 \%$ protein diets. Journal of Nutrition, 2000, 130: 813-819.

79. $\mathrm{M} \mathrm{c} \mathrm{D}$ a $\mathrm{n}$ i e 1 C.D., B r a m w e 11 R.K., $\mathrm{H}$ o w a $\mathrm{rth}$ J.B. The male contribution to broiler breeder heat induced infertility as determined by sperm-egg penetration and sperm storage within the hen's oviduct. Poultry Science, 1996, 75: 1546-1554.

80. McDaniel C.D., Hood J.E., Parker H.M. An attempt at alleviating heat stress infertility in male broiler breeder chickens with dietary ascorbic acid. Int. J. Poult. Sci., 2004, 3: 593-602. 